\title{
Prevalence of Low Level of Vitamin D Among COVID-19 Patients and Associated Risk Factors in India - A Hospital-Based Study
}

\author{
Shruti Singh' \\ Nirav Nimavat (iD ${ }^{2}$ \\ Amarjeet Kumar Singh ${ }^{3}$ \\ Shamshad Ahmad ${ }^{4}$ \\ Nishi Sinha ${ }^{2}$ \\ 'Department of Pharmacology, AlIMS, \\ Patna, Bihar, India; ${ }^{2}$ Department of \\ Community Medicine, SBKS MIRC, \\ Sumandeep Vidyapeeth Deemed to be \\ University, Vadodara, Gujarat, India; \\ ${ }^{3}$ Department of Anaesthesia, AlIMS, \\ Patna, Bihar, India; ${ }^{4}$ Department of \\ Community and Family Medicine, AlIMS, \\ Patna, Bihar, India
}

Correspondence: Nirav Nimavat Department of Community Medicine, SBKS MIRC, Sumandeep Vidyapeeth Deemed to be University, Vadodara, Gujarat, India

Email nkniraj1529@gmail.com
Background: The world is facing the most challenging pandemic in the 21 st century. The developed and developing countries are facing the burden equally and no proven treatment options available. Recent studies suggest the plausibility of vitamin D therapy and prophylaxis for COVID-19, in the setting where the deficiency is more prevalent. Though evaluation of vitamin D status is not a routine in India, the present study focuses on the level of Vitamin d among COVID-19 patients.

Methods: The study was a hospital-based cross-sectional to find the status of vitamin D among COVID-19 patients in a tertiary care hospital, Patna, Bihar, India. The demographic, comorbidity data were taken, and the level of vitamin D was measured by a chemiluminescence-based immunoassay analyzer. The analysis compared the level of deficiency and insufficiency among different groups of COVID-19 patients. The role of DM and HTN as risk factors for mortality was compared.

Results: Among the total study participants (156), 42.31\% were obese and $17.31 \%$ were severe as per clinical severity. The total prevalence of vitamin D deficiency was $58.97 \%$ and insufficiency was $89.1 \%$. The prevalence was found high among male $(61.02 \%)$, overweight $(65.52 \%)$, and severe $(62.96 \%)$ patients. The severity increases with advanced age $(\mathrm{p}<0.05)$ and important risk factors for mortality are DM, HTN, and advanced age.

Conclusion: The level of vitamin D can be assessed for the prognosis of COIVD-19 patients and help to modify the treatment protocol. Appropriate therapeutic/preventive intervention of vitamin D can alter the course and severity of COVID-19.

Keywords: Vitamin D, COVID-19, SARS-CoV-2, low level of Vitamin D

\section{Introduction}

In December of the year 2019, an outbreak of pneumonia of unknown cause in Wuhan, China was reported to the World Health Organization (WHO) China Country Office. With the turn of the year (2020), increasing cases of this novel coronavirus were reported in different countries across the globe. The disease was later on named Coronavirus disease 2019 or COVID-19 and by March 2020, it was declared a pandemic by the WHO. ${ }^{1}$

As of January 2021, a little over a year after the virus was first reported, the virus has infected at least 90 million people across the globe. Furthermore, it has taken 1.9 million lives worldwide. ${ }^{2}$ With no known cure, medical practitioners all over the world were left with no treatment options, and while the vaccine developed with efficacy and safety in a query, the virus continuously spread infecting and killing more and more people. 
Without a defined treatment protocol for COVID-19, medical practitioners were forced to find the best ways to manage the symptoms of infected patients and to prevent further complications. The curiosity of the scientific community was triggered by the lack of a cure and vaccine for COVID-19. While vaccine research is ongoing, scientific researchers began their search for a potential cure for COVID-19. One of the things that researchers investigated was the effect of Vitamin D deficiency on the progression of COVID-19.

\section{Vitamin D}

While Vitamin D is commonly known for its contribution to bone health and metabolism of calcium and phosphorus, it has also been known to have an important function in the immune system. ${ }^{3,4}$ Vitamin D was found to have a critical role as an "immunomodulator". 5 Vitamin $\mathrm{D}$ modulates the body's immune response during infection. ${ }^{3}$

Vitamin D modulates both the innate immune system and the adaptive immune system by increasing the cathelicidins and B-defensins levels in the body, and by reducing the secretion of immunoglobulin by plasma cells and the production of pro-inflammatory cytokines, respectively. ${ }^{3,6}$ It has both antimicrobial and antiinflammatory effects and is known to be effective in preventing various upper respiratory tract infections (RTIs). ${ }^{4,5}$ It also has the potential to prevent or lessen the possibility of having complications from RTIs. ${ }^{6}$ Vitamin D can also hasten the healing process of affected areas, specifically lung tissues. ${ }^{5}$

\section{Vitamin D Deficiency and COVID-19}

Vitamin D deficiency has been associated with increased levels of inflammatory cytokines and increased risk of pneumonia and viral upper respiratory tract infections. ${ }^{7}$ It is also an important risk factor for acute respiratory distress syndrome (ARDS), which is an important determinant of the severity of illness among COVID-19 patients. $^{7,8}$ Vitamin D deficiency is also associated with increased episodes of thrombosis, which is commonly observed among COVID-19 patients. $^{7}$

A low level of Vitamin D is commonly observed among those in the older age group, obese, and smokers, and among patients with chronic diseases like hypertension, gastroenterological disease, and diabetes. ${ }^{9}$ It is also among these groups that COVID-19 was observed to be more prevalent and have more severe complications. ${ }^{6}$ As per various literature sources, deficiency of Vitamin D is common in India, the Middle East, South America, Africa, and Australia. ${ }^{10-12}$

With the observation that the group of people with Vitamin D deficiency are also the same group suffering from more complications and higher mortality from COVID-19, then Vitamin D deficiency might be an important risk factor for COVID-19. The patients with one of the fat malabsorption syndrome and bariatric patients are usually not able to absorb the fat-soluble vitamin, and the patients with the nephritic syndrome also lose $25(\mathrm{OH})$ $\mathrm{D}$ bound to the Vitamin D binding protein in the urine. ${ }^{10}$ This paper intends to look into the prevalence of Vitamin D deficiency among COVID-19 patients and other risk factors.

This study has employed a cross-sectional study design to determine the prevalence of Vitamin D deficiency among COVID-19 patients and to determine whether a low level of Vitamin D is a significant risk for COVID-19. The result of this study can be used as a basis for stricter clinical trials to consequently determine whether Vitamin D supplementation would be a good part of clinical management for COVID-19.

\section{Materials and Methods}

\section{Aim}

The study aimed to find the prevalence of low levels of Vitamin D among COVID-19 patients and associated risk factors.

\section{Study Design and Setting}

The present study was conducted at tertiary care dedicated COVID-19 hospital in Patna, Bihar, India. The duration of the study was 1.5 months (1st Aug 2020 to 15th Sep 2020). Those who tested positive in RT-PCR were taken from the wards and Flu clinic of the hospital. To calculate the sample size for cross-sectional study, enough literature for Vitamin D and COVID-19 in India was not available. Therefore, all patients were enrolled consecutively over 1.5 months.

\section{Study Participant Selection}

Inclusion criteria: Those who tested positive (RT-PCR) for SARS-CoV-2 from Flu clinic and COVID ward were included. 
Exclusion criteria: Those who were taking Vitamin D supplements or having taken them in the last 6 months were excluded.

\section{Statistical Analysis}

Data were collected on a pre-validated Case Recording Form. The demographic data of all the COIVD-19 patients were recorded. Comorbid conditions like diabetes and hypertension were also recorded. History of alcohol consumption and smoking was recorded. The sample for Vitamin D along with routine investigations was sent and the level of Vitamin D was estimated using chemiluminescence-based immunoassay analyzer ADVIA CENTAUR XP (siemens). ${ }^{13}$

All the data were entered into Microsoft excel 365 version and analyzed using SPSS (Statistical Package for Social Science) version 27.0.1.0. ${ }^{14}$ All the demographic data were analyzed to be presented in frequencies and percentages. The classification of Vitamin D deficiency, clinical severity, and body mass index was defined. To find out the association, the chi-square test was applied and a p-value less than 0.05 was considered statistically significant. To understand the Vitamin D status among the different groups, deficiency, and insufficiency were calculated separately and compared. Further stratification of data was carried out in mean and standard deviation to get the overall picture of the respective group. Data of clinical severity were compared to check the association between clinical severity, Vitamin D level, and age. The mortality data were compared with age, sex, Vitamin D, DM, and HTN.

\section{Ethical Consideration}

All the patients were informed about the purpose of the study and written/digital consent was taken to participate in the study. The study protocol was approved by the institutional ethical committee of All India Institute of Medical Science, Patna (ECR/1387/Inst/BR/2020) and the approval number for the study is AIIMS/Pat/IEC/ 2020/501. The study has been conducted as per the Declaration of Helsinki.

\section{Classification Vitamin D (Serum 25-Hydroxy Vitamin D [25(OH)D] Levels}

Patients were classified into different groups according to their serum 25(OH) Vitamin D levels. Serum 25(OH) Vitamin D level $>30 \mathrm{ng} / \mathrm{mL}$ was classified as normal. Vitamin D insufficiency and deficiency were defined as serum $25(\mathrm{OH})$ Vitamin D levels of $20-30 \mathrm{ng} / \mathrm{mL}$ and $<20$ $\mathrm{ng} / \mathrm{mL}$, respectively. ${ }^{15}$

\section{Classification of Patient Severity}

The patients were classified into three groups based on severity. The classification of the patients was based on the guidelines of the Ministry of Health and Family Welfare, India. ${ }^{16}$ As per the guideline, the classification of the patients was based on clinical parameters as following:

(1) Mild case: Without evidence of breathlessness or hypoxia (normal saturation)

(2) Moderate case: the presence of clinical features of dyspnea and/or hypoxia, fever, cough, including SpO2 $<94 \%$ (range $90-94 \%$ ) on room air, Respiratory Rate more or equal to 24 per minute

(3) Severe case: clinical signs of Pneumonia plus one of the following; respiratory rate $>30$ breaths $/ \mathrm{min}$, severe respiratory distress, $\mathrm{SpO} 2<90 \%$ on room air

\section{BMI Classification}

For classifying obesity, we followed the guideline of the World Health Organization for the Asia-pacific region. As per the guideline, the criteria are as following: ${ }^{17}$

(a) Underweight were those whose BMI was $<18.5 \mathrm{~kg} / \mathrm{m}^{2}$

(b) Normal having BMI of $18.5-22.9 \mathrm{~kg} / \mathrm{m}^{2}$

(c) Overweight was having BMI of $23-24.9 \mathrm{~kg} / \mathrm{m}^{2}$

(d) Obese having BMI of $\geq 25 \mathrm{~kg} / \mathrm{m}^{2}$

\section{Results}

\section{Study Population Characteristics}

The study included 156 COVID-19 patients. The basic characteristics of the patients are described in Table 1. Among total patients, males were represented more than females ( $75.64 \%$ vs $24.36 \%$ ). The mean age of the patients was $41.6 \pm 16.4$ years and most of the patients $(>60 \%)$ were $\geq 50$ years and 20-29 years. More than one-third of the patients (42.31\%) of the cases were obese, while $31.41 \%$ had normal BMI. On the categorization of patients based on severity, 109 (69.87\%) were mild, 20 (12.82\%) were moderate and $27(17.31 \%)$ were severe. $23.7 \%$ were consuming alcohol and $25 \%$ were a smoker. Concerning co-morbid conditions, $10.9 \%$ had diabetes and $10.3 \%$ had hypertension.

\section{Prevalence of Vitamin D Deficiency and Insufficiency}

Table 2 describes the prevalence of Vitamin D deficiency among the different categories. Prevalence of Vitamin $\mathrm{D}$ deficiency and insufficiency was, $61.02 \%$ (mean level of $13.07 \mathrm{ng} / \mathrm{mL} \pm 4.28$ ) and $89.83 \%$ (mean level of $16.57 \mathrm{ng} /$ 
Table I Distribution of Cases as per Gender, Age, BMI, and Severity

\begin{tabular}{|c|c|}
\hline Gender & Cases (\%) $N=156$ \\
\hline Male & II 8 (75.64) \\
\hline Female & $38(24.36)$ \\
\hline Age group (years) & Cases (\%) \\
\hline $20-29$ & $47(30.13)$ \\
\hline $30-39$ & $4 \mid(26.28)$ \\
\hline $40-49$ & $17(10.90)$ \\
\hline$\geq 50$ & 51 (32.69) \\
\hline Mean Age, SD & $41.6,16.4$ \\
\hline BMI Classification & Cases (\%) \\
\hline Underweight $\left[<18.5 \mathrm{~kg} / \mathrm{m}^{2}\right]$ & $12(7.69)$ \\
\hline Normal [ $18.5-22.9 \mathrm{~kg} / \mathrm{m}^{2}$ & $49(3 I .4 I)$ \\
\hline Overweight $\left[23-24.9 \mathrm{~kg} / \mathrm{m}^{2}\right]$ & $29(18.59)$ \\
\hline Obese $\left[\geq 25 \mathrm{~kg} / \mathrm{m}^{2}\right]$ & $66(42.3 I)$ \\
\hline Mean BMI, SD & $24.46,4.8$ \\
\hline Severity among cases & Cases (\%) \\
\hline Mild & $109(69.87)$ \\
\hline Moderate & $20(12.82)$ \\
\hline Severe & $27(17.31)$ \\
\hline Consuming alcohol & $37(23.7)$ \\
\hline Not consuming alcohol & $119(76.3)$ \\
\hline Smoker & $39(25)$ \\
\hline Non-smoker & $117(75)$ \\
\hline Diabetic & $17(10.9)$ \\
\hline Non-diabetic & $139(89.1)$ \\
\hline Hypertensive & $16(10.3)$ \\
\hline Non-hypertensive & | 40 (89.7) \\
\hline
\end{tabular}

$\mathrm{mL} \pm 6.37$ ), respectively, among males. Among different age groups, the prevalence of Vitamin D deficiency was high in 20-29 (68.08\%) years with a mean level of $14.60 \mathrm{ng} / \mathrm{mL} \pm$ 3.84 and $30-39(60.97 \%)$ years with a mean level of 14.07 $\mathrm{ng} / \mathrm{mL} \pm 4.16$. Vitamin D insufficiency was also reported high among these age groups, $95.74 \%$, and $92.68 \%$, respectively. The study reported $65.52 \%$ deficiency and $93.10 \%$ insufficiency of Vitamin D among the overweight group
(BMI 23-24.9 kg/m²). Obese patients $\left(\geq 25 \mathrm{~kg} / \mathrm{m}^{2}\right.$ ) with Vitamin D deficiency (56.06\%) had a mean level of 11.43 $\mathrm{ng} / \mathrm{mL} \pm 3.89$, while those with insufficiency (87.88\%) had a mean level of $15.84 \mathrm{ng} / \mathrm{mL} \pm 6.80$. Among the severe patients, the deficiency of Vitamin D was $62.96 \%$ (mean level of $9.38 \mathrm{ng} / \mathrm{mL} \pm 2.54$ ) and insufficiency was $85.19 \%$ (mean level of $19.65 \mathrm{ng} / \mathrm{mL} \pm 7.76$ ). The patients with mild clinical severity had a mean level of $14.45 \mathrm{ng} / \mathrm{mL} \pm 3.96$ among the Vitamin D deficient group and a mean level of $17.63 \mathrm{ng} / \mathrm{mL} \pm 5.57$ among the insufficient group.

\section{Vitamin D, Clinical Severity and Risk Factors for Mortality}

Table 3 shows the analysis of Vitamin D among various clinical severity groups, and the difference was not statistically significant ( $\mathrm{p}$-value $>0.05$ ). Association between clinical severity and age groups was highly significant ( $p$-value $<0.00001$ ) as presented in Table 4 . The comparison of different risk factors for mortality among cases is presented in Table 5. Among these, mortality was proportionally higher among males $(88.89 \%)$, age $\geq 50$ years $(88.89 \%)$, obese $(61.11 \%)$, and Vitamin D deficient group $(61.11 \%)$. The most important risk factors for the cause of death were age, presence of DM, and HTN, which were statistically significant $(\mathrm{p}=<0.05)$.

\section{Discussion}

Vitamin D has reportedly interacted with multiple organ systems and is a highlighting factor in COVID-19 infection. Since the 1930s, Vitamin D has been used for the treatment and prevention of acute respiratory infections. ${ }^{18}$ Studies reported in the last era revealed Vitamin D protective effects although these effects showed substantial heterogeneity and were of modest size. ${ }^{19-23}$ The risk factors for Vitamin D deficiency overlap strikingly with severe COVID-19 including, but not limited to, obesity, age, ethnic origin. ${ }^{23}$ Our study also reports the highest level of Vitamin D deficiency in obese patients (mean of $11.43 \mathrm{ng} / \mathrm{mL}$ for BMI $>25 \mathrm{~kg} / \mathrm{m}^{2}$ ) among all reported cases (Table 3). This overlap led scientists to hypothesize that treatment for Vitamin D deficiency might exhibit a non-therapeutic effect for COVID-19. We report an increased death rate among the elderly (Age $>50$ years), pre-existing hypertension, and diabetes mellitus (Table 5). The statistics revealed that among all the reported cases, $61.02 \%$ of males were deficient compared to $52.63 \%$ females and deficiency was reported among all ages 
Table 2 Prevalence of Vitamin D Deficiency and Insufficiency Among Different Groups

\begin{tabular}{|c|c|c|c|c|c|c|}
\hline & $\begin{array}{c}\text { Vit D Deficient } \\
\text { Cases <20 ng/ } \\
\text { mL (Mean, SD) }\end{array}$ & $\begin{array}{c}\text { Vit } \\
\text { D Deficiency } \\
\text { Prevalence \% }\end{array}$ & $\begin{array}{c}\text { Vit } \\
\text { D Deficiency } \\
\text { Proportion \% }\end{array}$ & $\begin{array}{l}\text { Vit D Insufficient Cases } \\
<30 \text { ng/mL (Mean, SD) * } \\
\text { Insufficient Level } \\
\text { Includes Deficiency }\end{array}$ & $\begin{array}{c}\text { Vit } \\
\text { D Insufficiency } \\
\text { Prevalence \% }\end{array}$ & $\begin{array}{c}\text { Vit } \\
\text { D Insufficiency } \\
\text { Proportion \% }\end{array}$ \\
\hline \multicolumn{7}{|c|}{ Prevalence in both genders } \\
\hline Male & $72(13.07,4.28)$ & 61.02 & 46.15 & $106(16.57,6.37)$ & 89.83 & 67.95 \\
\hline Female & $20(13.94,4.04)$ & 52.63 & 12.82 & $33(17.53,5.72)$ & 86.84 & 21.15 \\
\hline \multicolumn{7}{|c|}{ Prevalence in different age groups } \\
\hline $20-29$ & $32(14.60,3.84)$ & 68.08 & 20.51 & $45(16.98,5.11)$ & 95.74 & 28.85 \\
\hline $30-39$ & $25(14.07,4.16)$ & 60.97 & 16.03 & $38(17.08,5.54)$ & 92.68 & 24.36 \\
\hline $40-49$ & $8(|2.79,4.5|)$ & 47.06 & 5.13 & $13(18.08,7.82)$ & 76.47 & 8.33 \\
\hline$\geq 50$ & $27(11.07,3.93)$ & 52.94 & $|7.3|$ & $43(15.98,7.33)$ & 84.31 & 27.56 \\
\hline \multicolumn{7}{|c|}{ Prevalence in Different BMI groups } \\
\hline $\begin{array}{l}\text { Underweight } \\
{\left[<18.5 \mathrm{~kg} / \mathrm{m}^{2}\right]}\end{array}$ & $6(16.71,1.84)$ & 50 & 3.85 & $10(20.21,5.01)$ & 83.33 & 6.41 \\
\hline $\begin{array}{l}\text { Normal } \\
{[18.5-22.9 \mathrm{~kg} /} \\
\mathrm{m}^{2}\end{array}$ & $30(14.08,3.84)$ & 61.22 & 19.23 & $44(|7.0|, 5.54)$ & 89.79 & 28.21 \\
\hline $\begin{array}{l}\text { Overweight } \\
{[23-24.9 \mathrm{~kg} /} \\
\left.\mathrm{m}^{2}\right]\end{array}$ & $19(14.50,4.75)$ & 65.52 & 12.18 & $27(17.4 I, 6.16)$ & 93.10 & 17.31 \\
\hline $\begin{array}{l}\text { Obese }[\geq \\
\left.25 \mathrm{~kg} / \mathrm{m}^{2}\right]\end{array}$ & $37(11.43,3.89)$ & 56.06 & 23.72 & $58(15.84,6.80)$ & 87.88 & 37.18 \\
\hline \multicolumn{7}{|c|}{ Prevalence in different severity groups } \\
\hline Mild & $64(14.45,3.96)$ & 58.72 & 41.03 & $99(17.63,5.57)$ & 90.82 & 63.46 \\
\hline Moderate & II $(12.38,4.22)$ & 55 & 7.05 & $17(16.23,6.45)$ & 85 & 10.90 \\
\hline Severe & $17(9.38,2.54)$ & 62.96 & 10.9 & $23(13.65,7.76)$ & 85.19 & 14.74 \\
\hline $\begin{array}{l}\text { Total } \\
\text { Prevalence }\end{array}$ & \multicolumn{3}{|c|}{58.97} & \multicolumn{3}{|c|}{89.1} \\
\hline
\end{tabular}

Table 3 Association of Vitamin D Among Cases Based on the Severity

\begin{tabular}{|c|c|c|c|c|c|}
\hline & $\begin{array}{c}\text { Deficient (Vit } D<20 \mathrm{ng} / \\
\mathrm{mL})\end{array}$ & $\begin{array}{c}\text { Insufficient (Vit D 20-30 ng/ } \\
\mathrm{mL})\end{array}$ & $\begin{array}{c}\text { Normal (Vit } \mathbf{D}>\mathbf{3 0} \mathrm{ng} / \\
\mathrm{mL})\end{array}$ & $P$ value & $\begin{array}{c}\text { Chi } \\
\text { Square }\end{array}$ \\
\hline Mild & 64 (69.57) & 35 (74.46) & $10(58.82)$ & \multirow{3}{*}{$\begin{array}{l}0.7695 \\
(>0.05)\end{array}$} & \multirow[t]{3}{*}{1.816} \\
\hline Moderate & II (II.96) & $6(12.77)$ & $3(17.65)$ & & \\
\hline Severe & 17 (18.47) & $6(12.77)$ & $4(23.53)$ & & \\
\hline
\end{tabular}

(Table 2). Whereas the proportion of cases as per severity did not differ by level of Vitamin D. Similar to reported results, our data also shows decreased fatality in patients aged $<50$ years. We also report patients aging less than 50 years to display non-severe disease (asymptomatic to mild) whereas patients aging more than 50 years display increased clinical severity. The findings of study by Ilie et al also suggest the hypothesis that ageing population has very low level of Vitamin D, which is also a vulnerable group for COVID-19. ${ }^{24}$

Metabolites of Vitamin D support innate antiviral effector mechanisms such as induction of autophagy and 
Table 4 Association Between Clinical Severity and Age Among Cases

\begin{tabular}{|c|c|c|c|c|c|}
\hline & Age $<50$ Years & Age $>50$ Years & Total & Chi Square & $P$ value \\
\hline Not Severe (Mild) & 95 & 14 & 109 & \multirow[t]{3}{*}{64.77} & \multirow[t]{3}{*}{$<0.0000$ I } \\
\hline Severe (Moderate \& Severe) & 10 & 37 & 47 & & \\
\hline Total & 105 & 51 & 156 & & \\
\hline
\end{tabular}

antimicrobial peptides. ${ }^{25-27}$ There is limited information on the correlation between blood picture and laboratory findings of Vitamin D and COVID-19, ${ }^{28}$ but it has also been reported that biologically active steroid hormone Vitamin D metabolite 1,25-dihydroxy Vitamin D (1,25 $(\mathrm{OH}) 2 \mathrm{D})$ exhibited antiviral inhibitory effect in human nasal epithelial cells infected with COVID virus. ${ }^{29-31}$ Animal studies show that the immunopathological inflammatory responses elicited by Vitamin D were regulated by the renin-angiotensin system (RAS). ${ }^{32}$ Overactivation of RAS has a poor prognosis in the context of severe COVID-19. The Renin-angiotensin-aldosterone system (RAAS) is also responsible for regulating volume and electrolyte homeostasis. ${ }^{33}$ Increased activation of this system leads to arterial hypertension. As shown in our results, patients suffering from hypertension were more prone to
COVID-19. ${ }^{34}$ Kidney cells are responsible for synthesizing renin stimulates aldosterone and angiotensin II production increasing blood pressure by either direct (vasoconstriction) or indirectly (retention of salt and water). ${ }^{35}$ Animal studies conducted have reported Vitamin D can be used to treat increased RAAS activation that in turn leads to arterial hypertension and/or myocardial abnormalities. ${ }^{36,37}$ Research on the mechanism of action of Vitamin D on RAAS revealed that it suppresses renin expression by binding to CREB (cAMP-response element-binding protein). ${ }^{38}$ Vitamin $\mathrm{D}$ inhibits the stimulation of renin transcription by restricting CREB binding to the promoter region of the renin gene. Human data show an inverse relation between $1,25(\mathrm{OH}) 2 \mathrm{D}$ with renin activation and arterial hypertension. ${ }^{39}$ Interestingly, Vitamin D treatment has been linked to decreased

Table 5 Association of Various Risk Factors for Mortality Among Cases

\begin{tabular}{|c|c|c|c|c|c|c|}
\hline \multicolumn{2}{|c|}{ Risk Factor } & \multirow{2}{*}{$\begin{array}{c}\text { Death (\%) } \mathbf{N}=18 \\
16(88.89) \\
2(11.11)\end{array}$} & \multirow{2}{*}{$\begin{array}{c}\text { No Death (\%) } \mathbf{N}=138 \\
102(73.91) \\
36(26.09)\end{array}$} & \multirow{2}{*}{$\frac{P \text { value }}{0.1638(>0.05)}$} & \multirow{2}{*}{$\frac{\text { Chi Square }}{1.93}$} & \multirow{2}{*}{$\frac{\text { OR }}{2.8}$} \\
\hline Sex & $\begin{array}{l}\text { Male } \\
\text { Female }\end{array}$ & & & & & \\
\hline Age & $\begin{array}{l}<50 \\
\geq 50\end{array}$ & $\begin{array}{c}2(11.11) \\
16(88.89)\end{array}$ & $\begin{array}{c}103(74.64) \\
35(25.36)\end{array}$ & $0.0000012(<0.00001)$ & 29.20 & 0.04 \\
\hline BMI & $\begin{array}{l}\text { Normal }\left(<23 \mathrm{~kg} / \mathrm{m}^{2}\right) \\
\text { Overweight }\left(23-24.9 \mathrm{~kg} / \mathrm{m}^{2}\right) \\
\text { Obese }\left(\geq 25 \mathrm{~kg} / \mathrm{m}^{2}\right)\end{array}$ & $\begin{array}{l}5(27.78) \\
2(11.11) \\
11(6 I .11)\end{array}$ & $\begin{array}{l}56(40.58) \\
27(19.56) \\
55(39.86)\end{array}$ & $0.2254(>0.05)$ & 2.98 & \\
\hline Alcohol & $\begin{array}{l}\text { Yes } \\
\text { No }\end{array}$ & $\begin{array}{c}2(11.11) \\
16(88.89)\end{array}$ & $\begin{array}{c}35(25.36) \\
103(74.64)\end{array}$ & $0.1812(>0.05)$ & 1.78 & 0.37 \\
\hline Smoking & $\begin{array}{l}\text { Yes } \\
\text { No }\end{array}$ & $\begin{array}{c}5(27.78) \\
13(72.22)\end{array}$ & $\begin{array}{c}34(24.64) \\
104(75.36)\end{array}$ & $0.772(>0.05)$ & 0.08 & 1.17 \\
\hline DM & $\begin{array}{l}\text { Yes } \\
\text { No }\end{array}$ & $\begin{array}{c}5(27.78) \\
13(72.22)\end{array}$ & $\begin{array}{c}12(8.70) \\
126(91.30)\end{array}$ & $0.0145(<0.05)$ & 5.97 & 4.04 \\
\hline HTN & $\begin{array}{l}\text { Yes } \\
\text { No }\end{array}$ & $\begin{array}{c}7(38.89) \\
\text { II (6I.II) }\end{array}$ & $\begin{array}{c}9(6.52) \\
129(93.48)\end{array}$ & $0.000021(<0.0001)$ & 18.12 & 9.12 \\
\hline Vit $D$ level & $\begin{array}{l}\text { Deficient }(<20 \mathrm{ng} / \mathrm{mL}) \\
\text { Insufficient }(20-30 \mathrm{ng} / \mathrm{mL}) \\
\text { Normal }(>30 \mathrm{ng} / \mathrm{mL})\end{array}$ & $\begin{array}{l}\text { II }(61.11) \\
4(22.22) \\
3(16.67)\end{array}$ & $\begin{array}{l}81(58.70) \\
43(31.16) \\
14(10.14)\end{array}$ & $0.588(>0.05)$ & 1.06 & \\
\hline
\end{tabular}


angiotensin II and renin levels in multiple studies. ${ }^{40-42}$ Our data show a significant role of hypertension among COVID-19 patients with increased mortality, which can be reduced with Vitamin D intake.

Consistent with our results, a recent study showed that nearly $75 \%$ of hospitalized and $85 \%$ of ICU care patients symptomatic for COVID-19 patients suffered Vitamin D insufficiency. ${ }^{43}$ A recent study that assessed inflammatory response and lung involvement found that Vitamin D deficiency was associated with altered inflammatory response and higher lung involvement. ${ }^{44}$ It was also reported that in European countries, Vitamin D deficiency was directly correlated to high COVID-19 infection rates and death. ${ }^{45}$ Another study from Indonesia found a $90 \%$ prevalence of Vitamin D deficiency among COVID-19 patients. ${ }^{46}$ Age is an important risk factor for the severity and mortality among cases. The earlier epidemiological study from China found that mortality increases with advanced age, ${ }^{47}$ which is consistent with our findings of severity increases with age. Munshi et al conducted in the United States showed a strong correlation between poorer outcomes or mortality in COVID 19 patients with Vitamin D deficiency. ${ }^{48}$ Patients suffering from diabetes mellitus also constitute a high risk for COVID-19 infection. It has been a prominent risk factor in the progression of acute respiratory distress and mortality in patients admitted with COVID-19. Congruent to our data, Yang and colleagues also reported that from the 32 fatalities from a group of 52 hospitalized patients in ICU due to COVID-19 infection in China, exhibiting distinctive comorbidities, $22 \%$ suffered from diabetes whereas another $22 \%$ suffered from cerebrovascular diseases. ${ }^{49}$ Alhazzani et al conducted a study from 12 different countries, reported that among 1099 patients admitted for COVID-19, 173 had severe infection with secondary comorbidities. Out of these comorbidities, $16.2 \%$ and $23.7 \%$ suffered from diabetes and hypertension, respectively. ${ }^{50}$ Similar to our findings, another study by Zhang et al has also been reported that among the 140 patients admitted for COVID-19 infection, 20\% were hypertensive patients, and $12 \%$ suffered from diabetes. ${ }^{51}$ Some patients in this study were being treated with ACE inhibitors, which is an inhibitor against angiotensinconverting enzyme; however, the possible effect of treatment for these comorbidities was not evaluated. ${ }^{51}$ Interestingly, SARS-CoV-2 virus responsible for COVID19 binds to their target through ACE in the epithelial cells of lungs, kidneys, and blood vessels. ${ }^{52}$ Diabetic patients have an increased expression of ACE2; therefore, ACE inhibitors are prescribed to regulate their role in disease etiology. In some instances, hypertension is also treated with ACE inhibitors. ${ }^{53}$ It can be speculated that increased ACE2 expression facilitates COVID-19 infection rate and untreated comorbidities such as diabetes and hypertension increase the risk of developing a severe and fatal COVID-19.

A recent review and meta-analysis showed that Vitamin D supplementation taken daily or weekly, reduces ARI (acute respiratory infection) by $32 \%$ to $60 \%$, thus having a protective effect and safe. ${ }^{54}$ An increase in the number of clinical trials has been registered recently to understand the effect of Vitamin D intake on COVID-19 outcomes. Available clinical trials give a preliminary picture of the interaction between infected patients and Vitamin D intake. There is also speculation in the scientific community that recent COVID-19 publications lack rigorous peer-reviewing; therefore, caution must be taken in the interpretation of the published results. The review done by Nurshad Ali concluded that a negative correlation between Vitamin D and COVID-19 was found among European countries, while retrospective studies found a correlation between Vitamin D and COVID-19 after adjusting the confounders. ${ }^{55}$ The review suggested supplementation of Vitamin D to the susceptible group. However, consistency of Vitamin D deficiency has been observed in patients with severe forms of COVID-19. As mentioned above, Vitamin $\mathrm{D}$ intake plays a significant role in controlling the homeostasis of the human body thus providing enough support to hypothesize Vitamin D insufficiency may lead to adverse outcomes. Until there is a definitive result, it is worldwide recommended to ensure adequate intake of Vitamin D.

\section{Conclusion}

The prevalence of Vitamin D deficiency and insufficiency in the present study was $58.97 \%$ and $89.1 \%$, respectively. The role of Vitamin D in the management of COVID-19 needs strong RCT evidence, but until then physicians should continue to treat deficiency and insufficiency of Vitamin D among COVID-19, as there are hardly any adverse effects.

\section{Abbreviations}

ARDS, acute respiratory distress syndrome; RT-PCR, reverse transcription-polymerase chain reaction; COVID- 
19, coronavirus disease 2019; RAAS, Renin-angiotensinaldosterone system.

\section{Key Message}

Vitamin D deficiency and insufficiency are more prevalent among COVID-19 patients. Its role in COID-19 patients should not be underestimated and supplementation with Vitamin D among patients can prevent worsening of disease severity.

\section{Institutional Review Board Statement}

The study protocol was approved by the institutional ethical committee of All India Institute of Medical Science, Patna (ECR/1387/Inst/BR/2020) and the approval number for the study is AIIMS/Pat/IEC/2020/501. The study has been conducted following the Declaration of Helsinki.

\section{Informed Consent Statement}

All the study participants were aware of the purpose of the study and informed consent was taken from all.

\section{Acknowledgments}

All the authors are thankful to the faculties and staff of AIIMS, Patna, Bihar for giving support and guidance in the study.

\section{Disclosure}

All the authors declare no conflicts of interest for this work.

\section{References}

1. Coronavirus (COVID-19) events as they happen. Available from: https://www.who.int/emergencies/diseases/novel-coronavirus-2019/ events-as-they-happen. Accessed January 17, 2021.

2. WHO Coronavirus Disease (COVID-19) Dashboard. WHO Coronavirus Disease (COVID-19) Dashboard. Available from: https://covid19.who.int/. Accessed May 18, 2021. Accessed January 17, 2021.

3. Panfili FM, Roversi M, D'Argenio P, Rossi P, Cappa M, Fintini D. Possible role of vitamin D in Covid-19 infection in pediatric population. J Endocrinol Invest. 2021;44(1):27-35. doi:10.1007/ s40618-020-01327-0

4. Aygun H. Vitamin D can prevent COVID-19 infection-induced multiple organ damage. Naunyn Schmiedebergs Arch Pharmacol. 2020;393 (7):1157-1160. doi:10.1007/s00210-020-01911-4

5. Mohan M, Cherian JJ, Sharma A. Exploring links between vitamin D deficiency and COVID-19. PLOS Pathog. 2020;16(9):e1008874. doi:10.1371/journal.ppat.1008874

6. Chandran M, Chan Maung A, Mithal A, Parameswaran R. Vitamin D in COVID - 19: dousing the fire or averting the storm? a perspective from the Asia-Pacific. Osteoporos Sarcopenia. 2020;6 (3):97-105. doi:10.1016/j.afos.2020.07.003
7. Weir EK, Thenappan T, Bhargava M, Chen Y. Does vitamin D deficiency increase the severity of COVID-19? Clin Med (Northfield Il). 2020;20(4):e107-e108. doi:10.7861/clinmed.2020-0301

8. Parekh D, Dancer RCA, Scott A, et al. Vitamin D to prevent lung injury following esophagectomy - a randomized, placebo-controlled trial. Crit Care Med. 2018;46(12):e1128-e1135. doi:10.1097/ CCM.0000000000003405

9. Siuka D, Pfeifer M, Pinter B. Vitamin D supplementation during the COVID-19 pandemic. Mayo Clin Proc. 2020;95(8):1804-1805. doi:10.1016/j.mayocp.2020.05.036

10. Holick MF. Vitamin D deficiency. $N$ Engl J Med. 2007;357 (3):266-281. doi:10.1056/NEJMra070553

11. Marwaha RK, Tandon N, Reddy DRHK, et al. Vitamin D and bone mineral density status of healthy schoolchildren in northern India. $\mathrm{Am}$ J Clin Nutr. 2005;82(2):477-482. doi:10.1093/ajcn.82.2.477

12. Thacher TD, Fischer PR, Strand MA, Pettifor JM. Nutritional rickets around the world: causes and future directions. Ann Trop Paediatr. 2006;26(1):1-16. doi:10.1179/146532806X90556

13. Siemens Healthcare GmbH.ADVIA Centaur XP Immunoassay System. Available from: https://www.siemens-healthineers.com/ immunoassay/systems/advia-centaur-xp.

14. SPSS Statistics - Overview | IBM; 2020. Available from: https:// www.ibm.com/products/spss-statistics. Accessed January 23, 2021.

15. Holick MF. Vitamin D status: measurement, interpretation, and clinical application. Ann Epidemiol. 2009;19(2):73-78. doi:10.1016/j. annepidem.2007.12.001

16. Ministry of Health and Family Welfare. Clinical management protocol: COVID-19; 2020:13. Available from: https://www.mohfw.gov.in/ pdf/ClinicalManagementProtocolforCOVID19.pdf. Accessed May $18,2021$.

17. World Health Organization. Regional Office for the Western Pacific. The Asia-Pacific Perspective: Redefining Obesity and Its Treatment. Sydney: Health Communications Australia; 2000.

18. Martineau AR, Forouhi NG. Vitamin D for COVID-19: a case to answer? Lancet Diabetes Endocrinol. 2020;8(9):735-736. doi:10.1016/S2213-8587(20)30268-0

19. Selvin E, Juraschek SP. Diabetes epidemiology in the COVID-19 pandemic. Diabetes Care. 2020;43(8):1690-1694. doi:10.2337/ dc20-1295

20. Fang M, Wang D, Tang O, Selvin E. Prevalence of chronic disease in laboratory-confirmed COVID-19 cases and U.S. Adults (2017-2018). Diabetes Care. 2020;43(10):e127-e128. doi:10.2337/dc20-1640

21. Kimberly E, Ng JPR. The effect of COVID-19 on patients with diabetes. US Pharm. 2020;45(11):9-12.

22. Riddle MC, Bakris G, Blonde L, et al. A lesson from 2020: public health matters for both COVID-19 and diabetes. Diabetes Care. 2021;44(1):8-10. doi:10.2337/dci20-0071

23. Klein SL, Pekosz A, Park H-S, et al. Sex, age, and hospitalization drive antibody responses in a COVID-19 convalescent plasma donor population. J Clin Invest. 2020;130(11):6141-6150. doi:10.1172/ JCI142004

24. Ilie PC, Stefanescu S, Smith L. The role of vitamin D in the prevention of coronavirus disease 2019 infection and mortality. Aging Clin Exp Res. 2020;32(7):1195-1198. doi:10.1007/s40520-020-01570-8

25. Lagishetty V, Liu NQ, Hewison M. Vitamin D metabolism and innate immunity. Mol Cell Endocrinol. 2011;347(1-2):97-105. doi:10.1016/ j.mce.2011.04.015

26. Bishop E, Ismailova A, Dimeloe SK, Hewison M, White JH. Vitamin $\mathrm{D}$ and immune regulation: antibacterial, antiviral, anti-inflammatory. JBMR Plus. 2020;jbm4.10405. doi:10.1002/jbm4.10405

27. Teymoori-Rad M, Shokri F, Salimi V, Marashi SM. The interplay between vitamin D and viral infections. Rev Med Virol. 2019;29(2): e2032. doi:10.1002/rmv.2032

28. Ohaegbulam KC, Swalih M, Patel P, Smith MA, Perrin R. Vitamin D supplementation in COVID-19 patients: a clinical case series. $\mathrm{Am}$ $J$ Ther. 2020;27(5):e485-e490. doi:10.1097/MJT.0000000000001222 
29. Merzon E, Tworowski D, Gorohovski A, et al. Low plasma $25(\mathrm{OH})$ vitamin D level is associated with increased risk of COVID-19 infection: an Israeli population-based study. FEBS J. 2020;287 (17):3693-3702. doi:10.1111/febs. 15495

30. Karahan S, Katkat F. Impact of serum 25(OH) Vitamin D level on mortality in patients with COVID-19 in Turkey. $J$ Nutr Health Aging. 2020. doi:10.1007/s12603-020-1479-0

31. Greiller CL, Martineau AR. Modulation of the immune response to respiratory viruses by vitamin D. Nutrients. 2015;7(6):4240-4270. doi: $10.3390 /$ nu 7064240

32. Meeker S, Seamons A, Maggio-Price L, Paik J. Protective links between vitamin D, inflammatory bowel disease and colon cancer World J Gastroenterol. 2016;22(3):933-948. doi:10.3748/wjg.v22. i3.933

33. Patel S, Rauf A, Khan H, Abu-Izneid T. Renin-angiotensinaldosterone (RAAS): the ubiquitous system for homeostasis and pathologies. Biomed Pharmacother. 2017;94:317-325. doi:10.1016/ j.biopha.2017.07.091

34. Chen Q, Xu L, Dai Y, et al. Cardiovascular manifestations in severe and critical patients with COVID-19. Clin Cardiol. 2020;43 (7):796-802. doi:10.1002/clc.23384

35. Wolf G. Renal injury due to renin-angiotensin-aldosterone system activation of the transforming growth factor-beta pathway. Kidney Int. 2006;70(11):1914-1919. doi:10.1038/sj.ki.5001846

36. Xiang W, Kong J, Chen S, et al. Cardiac hypertrophy in vitamin $\mathrm{D}$ receptor knockout mice: role of the systemic and cardiac renin-angiotensin systems. Am $J$ Physiol Endocrinol Metab. 2005;288(1):E125-32. doi:10.1152/ajpendo.00224.2004

37. Sanz R, Mazzei L, Santino N, Ingrasia M, Manucha W. Vitamin D-mitochondria cross-talk could modulate the signaling pathway involved in hypertension development: a translational integrative overview. Clin Investig Arterioscler. 32(4):144-155. doi:10.1016/j. arteri.2020.02.002

38. Legarth C, Grimm D, Wehland M, Bauer J, Krüger KM. The impact of Vitamin D in the treatment of essential hypertension. Int J Mol Sci. 2018;19(2):2. doi:10.3390/ijms19020455

39. Tomaschitz A, Pilz S, Ritz E, et al. Independent association between 1,25-dihydroxyvitamin D, 25-hydroxyvitamin $\mathrm{D}$ and the renin-angiotensin system: the Ludwigshafen Risk and Cardiovascular Health (LURIC) study. Clin Chim Acta. 2010;411 (17-18):1354-1360. doi:10.1016/j.cca.2010.05.037

40. Rammos G, Tseke P, Ziakka S. Vitamin D, the renin-angiotensin system, and insulin resistance. Int Urol Nephrol. 2008;40 (2):419-426. doi:10.1007/s11255-007-9244-4

41. de Borst MH, Vervloet MG, Ter Wee PM, Navis G. Cross talk between the renin-angiotensin-aldosterone system and vitamin D-FGF-23-klotho in chronic kidney disease. J Am Soc Nephrol. 2011;22(9):1603-1609. doi:10.1681/ASN.2010121251

42. Li YC, Qiao G, Uskokovic M, Xiang W, Zheng W, Kong J. Vitamin D: a negative endocrine regulator of the renin-angiotensin system and blood pressure. J Steroid Biochem Mol Biol. 2004;89-90(1-5):387-392. doi:10.1016/j.jsbmb.2004.03.004
43. Mendy A, Apewokin S, Wells AA, Morrow AL. Factors associated with hospitalization and disease severity in a racially and ethnically diverse population of COVID-19 patients. medRxiv Prepr Serv Heal Sci. 2020. doi:10.1101/2020.06.25.20137323

44. Ricci A, Pagliuca A, D’Ascanio M, et al. Circulating Vitamin D levels status and clinical prognostic indices in COVID-19 patients. Respir Res. 2021;22(1):76. doi:10.1186/s12931-021-01666-3

45. Carpagnano GE, Di Lecce V, Quaranta VN, et al. Vitamin $\mathrm{D}$ deficiency as a predictor of poor prognosis in patients with acute respiratory failure due to COVID-19. J Endocrinol Invest. 2020;44 (4):765-771. doi:10.1007/s40618-020-01370-x

46. Pinzon RT, Pradana AW. Vitamin D deficiency among patients with COVID-19: case series and recent literature review. Trop Med Health. 2020;48(1):102. doi:10.1186/s41182-020-00277-w

47. Epidemiology Working Group for NCIP Epidemic Response CC for DC and P. [The epidemiological characteristics of an outbreak of 2019 novel coronavirus diseases (COVID-19) in China]. Zhonghua Liu Xing Bing Xue Za Zhi. 2020;41(2):145-151. doi:10.3760/cma.j. issn.0254-6450.2020.02.003. [Chinese]

48. Munshi R, Hussein MH, Toraih EA, et al. Vitamin D insufficiency as a potential culprit in critical COVID-19 patients. J Med Virol. 2021;93(2):733-740. doi:10.1002/jmv.26360

49. Yang X, Yu Y, Xu J, et al. Clinical course and outcomes of critically ill patients with SARS-CoV-2 pneumonia in Wuhan, China: a single-centered, retrospective, observational study. Lancet Respir Med. 2020;8(5):475-481. doi:10.1016/S2213-2600(20)30079-5

50. Alhazzani W, Møller MH, Arabi YM, et al. Surviving sepsis campaign: guidelines on the management of critically ill adults with Coronavirus Disease 2019 (COVID-19). Crit Care Med. 2020;48 (6):e440-e469. doi:10.1097/CCM.0000000000004363

51. Zhang -J-J, Dong X, Cao -Y-Y, et al. Clinical characteristics of 140 patients infected with SARS-CoV-2 in Wuhan, China. Allergy. 2020;75(7):1730-1741. doi:10.1111/all.14238

52. Wan Y, Shang J, Graham R, Baric RS, Li F. Receptor recognition by the novel coronavirus from Wuhan: an analysis based on decade-long structural studies of SARS Coronavirus. J Virol. 2020;94(7). doi:10.1128/JVI.00127-20

53. Li XC, Zhang J, Zhuo JL. The vasoprotective axes of the renin-angiotensin system: physiological relevance and therapeutic implications in cardiovascular, hypertensive and kidney diseases. Pharmacol Res. 2017;125(Pt A):21-38. doi:10.1016/j. phrs.2017.06.005

54. Martineau AR, Jolliffe DA, Greenberg L, et al. Vitamin D supplementation to prevent acute respiratory infections: individual participant data meta-analysis. Health Technol Assess. 2019;23 (2):1-44. doi: $10.3310 /$ hta23020

55. Ali N. Role of vitamin D in preventing of COVID-19 infection, progression and severity. J Infect Public Health. 2020;13 (10):1373-1380. doi:10.1016/j.jiph.2020.06.021
International Journal of General Medicine

\section{Publish your work in this journal}

The International Journal of General Medicine is an international, peer-reviewed open-access journal that focuses on general and internal medicine, pathogenesis, epidemiology, diagnosis, monitoring and treatment protocols. The journal is characterized by the rapid reporting of reviews, original research and clinical studies
Dovepress

across all disease areas. The manuscript management system is completely online and includes a very quick and fair peer-review system, which is all easy to use. Visit http://www.dovepress.com/ testimonials.php to read real quotes from published authors. 